ICH 2019

International Conference on Humanities

\title{
FACTORS INFLUENCING LAND UTILIZATION AMONG POOR RURAL HOUSEHOLD IN KEDAH, MALAYSIA
}

\author{
Mohd Azmeer Abu Bakar (a)*, Asyirah Abdul Rahim (b) \\ *Corresponding author \\ (a) Mohd Azmeer Abu Bakar, School of Humanities, Universiti Sains Malaysia, 11800, Pulau Pinang, \\ azmeym@gmail.com \\ (b) Asyirah Binti Abdul Rahim, School of Humanities, Universiti Sains Malaysia, 11800, Pulau Pinang, \\ asyirah@usm.my
}

\begin{abstract}
The land resources are part of the natural assets that provide direct and indirect benefits to people, especially the rural poor. In poverty studies, utilization and management of the land are important to the livelihood of poor people, particularly in supplying food and generating income. Several factors influence the utilization of the land in their surrounding among rural poor household and the factors of influence in land utilization are also different when time and space are different. Therefore, these objectives are to determine the factors of influence in land utilization among poor rural households and analyse the relationships between land utilization and yield. The questionnaire survey was adopted, and 124 respondents were selected based on snowball sampling in Jerlun, Kedah. In this study, there are five main factors, namely are the social economy, spatial, physical, temporal and risk. Then, those factors which include seven variables will be analysed in multiple regression; are social interaction, level of technology, infrastructure, transportation, market accessing, season, and climate change. Based on multiple regression analysis, utilization factors are significant for social interaction, transportation and climate change. Final thought, the type of social interaction, mode of transportation and impact climate change to activity has influenced the poor rural household to utilize the land resources for their life survive.
\end{abstract}

2357-1330 (C) 2020 Published by European Publisher.

Keywords: Land resources, utilization factors, rural poor, multiple regression.

cC) Unported License, permitting all non-commercial use, distribution, and reproduction in any medium, provided the original work is properly cited. 


\section{Introduction}

Poverty has been a major issue for many countries. In Malaysia, poverty eradication policies managed to significantly reduce poverty rate. Although the poverty rate is relatively small, a pocket of poverty still exists across a geographic region. Therefore, we should explore the lives of the poor in rural areas how they manage their lives, especially in natural resources utilization. Natural resources have an important role in human life such as water, marine, and land (Ngang, 2015). Land resources are also one of the natural resources that can provide both direct and indirect benefits to human survival and provide vital goods and services that are crucial to the well-being of poor rural households (Dunnamah et al., 2016). Poor rural households often depend on land resources either as sources of income or to meet their consumption requirements (Organisation for Economic Co-Operation and Development, 2008). According to Selim et al. (2009) also said that rural poor people depend on agriculture and related activities for their livelihoods. Constantine (2016) and Abdullah and Mustafa (2011) stated land resources are places where provide a range of food to people such as herbs, vegetable, fruit and cooking plants in their life.

Besides that, management and land utilization are one of the process to get benefit of provisioning services from the land resources. Rural poor today, when a product taken from land resources, for example vegetable, fruit, and cooking plant just for their living, income and human well-being (Braat $\&$ de Groot, 2012; Millenium Ecosystem Assessment, 2005). Here, it has shown the relationship between the poor and natural resources (land) that is closely linked in support of human life and the local cultural features (Hetzler, 2012; Nyumbu, 2013). This is evidenced by Fonta et al. (2011) finding that a $10 \%$ increase in natural resource income is associated with a decline in the number of households in poverty of about $4.9 \%$ in Nigerian country.

\section{Problem Statement}

According to Hussain et al. (2017) role and benefit of natural resources differ from one place to another place and Thongyou (2014) had explained households will change as the environment changes. Then, the factors that influence land utilization among poor households also is different when it comes to difference time and space. By that, this study is responsible the responsibility to investigate the significant factors that influenced the land utilization and to analyse the relationships between factors that influence land utilization and yield derived from land resources.

\section{Research Questions}

Based on this study, post two (2) research question:

1. Whether significant factors influence land utilization

2.How the relationships between factors influence land utilization and yield had derived from land resources

\section{Purpose of the Study}

Our aim in this study is to determine the factors that influence land utilization among poor rural household and analyse the relationships between land utilization and yield which derived from land resources. 


\section{Research Methods}

\subsection{Target Participants}

The study was conducted to determine factors that influence utilization of ecosystem services, especially in provisioning services by the poor communities. Initially, the researchers conducted the study rural communities. About 179 households were registered in e-Kasih with a poverty rate of more than 1.0 (Ministry of Women, Family and Community Development, 2014).

\subsection{Data Analysis}

Questionnaire data were processed, coded and analyzed using the Statistical Package for Social Sciences (SPSS) software version 22. Descriptive statistics (percentage, mean, and frequency count) were used to characterize socioeconomic variables such as gender, age, and income. Multiple regression was used to determine the factors of influence land utilization among poor rural households and analyze the relationships between land utilization and yield. Seven variables will be analyzed in multiple regression are social interaction, level of technology, infrastructure, transportation, market accessing, season, and climate change refer on Table 01. The model of multiple regression (Bakar, 2007) used is specified as:

Table 01. Type of Variables

\begin{tabular}{|l|l|}
\hline \multicolumn{1}{|c|}{ Variables } & \multicolumn{1}{|c|}{ Sub-factors } \\
\hline Social Interactions & Type of Interaction \\
\hline$X_{1}$ & Size of Interaction \\
\hline$X_{2}$ & Interaction form \\
\hline$X_{3}$ & Type of tools \\
\hline Level of Technology & Form of technology \\
\hline$X_{4}$ & Time \\
\hline$X_{5}$ & Process \\
\hline$X_{6}$ & \multicolumn{2}{|l}{} \\
\hline$X_{7}$ & Type of Infrastructure \\
\hline Infrastructure & Infrastructure condition \\
\hline$X_{8}$ & \multicolumn{2}{|l}{} \\
\hline$X_{9}$ & Type of transportation \\
\hline Transportation & Transportation ability \\
\hline$X_{10}$ & Travel Time \\
\hline$X_{11}$ & \\
\hline$X_{12}$ & Distance \\
\hline Market Accessing & Demand \\
\hline$X_{13}$ & Activities \\
\hline$X_{14}$ & Yields \\
\hline Season & Yields \\
\hline$X_{15}$ & Activities \\
\hline$X_{16}$ & Cos \\
\hline Climate Change & \\
\hline$X_{17}$ & $X_{18}$ \\
\hline$X_{19}$ & \\
\hline
\end{tabular}




$$
\begin{array}{lll}
\mathrm{Y}=\beta_{0}+\beta_{1} \mathrm{X}_{1}+\beta_{2} \mathrm{X}_{2}+\beta_{3} \mathrm{X}_{3}+\beta_{4} \mathrm{X}_{4}+\beta_{5} \mathrm{X}_{5}+\beta_{6} \mathrm{X}_{6} \ldots \ldots \ldots+\beta_{\mathrm{n}} \mathrm{X}_{\mathrm{n}}+\varepsilon \quad \ldots \text { Equation; } 1.0 \\
\text { Here }, & \\
\mathrm{Y} & =\text { Independent Variable } \\
\mathrm{B}_{0} & =\text { Constant } \\
\mathrm{B}_{1} \beta_{2} & =\text { Coefficient regression } \\
\mathrm{X}_{1} \mathrm{X}_{2} & =\text { Dependent Variable } \\
\varepsilon & =\text { Error }]
\end{array}
$$

\subsection{Data Collection}

Data were collected detailed from the household head survey field. A household head was used as the basic unit of the survey. In this regard, a household was defined as a group of people living together, making common arrangements for food and other essentials for a living (Kamwi et al., 2018). A questionnaire survey was adopted, and 124 household heads were selected based on snowball sampling in sub-district Jerlun, Kedah. The households selected are low-income which identified as household earning less than RM1200 per month (without government assistance). The questionnaire survey mainly focused on socio-demographic information of household head and their livelihood activities based on land resources, and factors of influence land utilization among poor households in the study area.

\subsection{Study Area}

The study was conducted in sub-district Jerlun, Kubang Pasu District (refer Figure 01). According to the Kubang Pasu District Council (2016), there are 167 villages in Jerlun Sub-district with a population of 53,383 people (of which Malay ninety per cent, Chinese eight per cent and others two per cent). Besides, the availability of natural resources, especially land agriculture meets the criteria of the study.
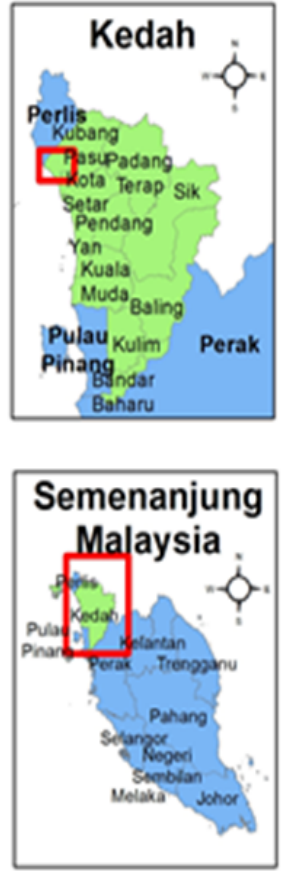

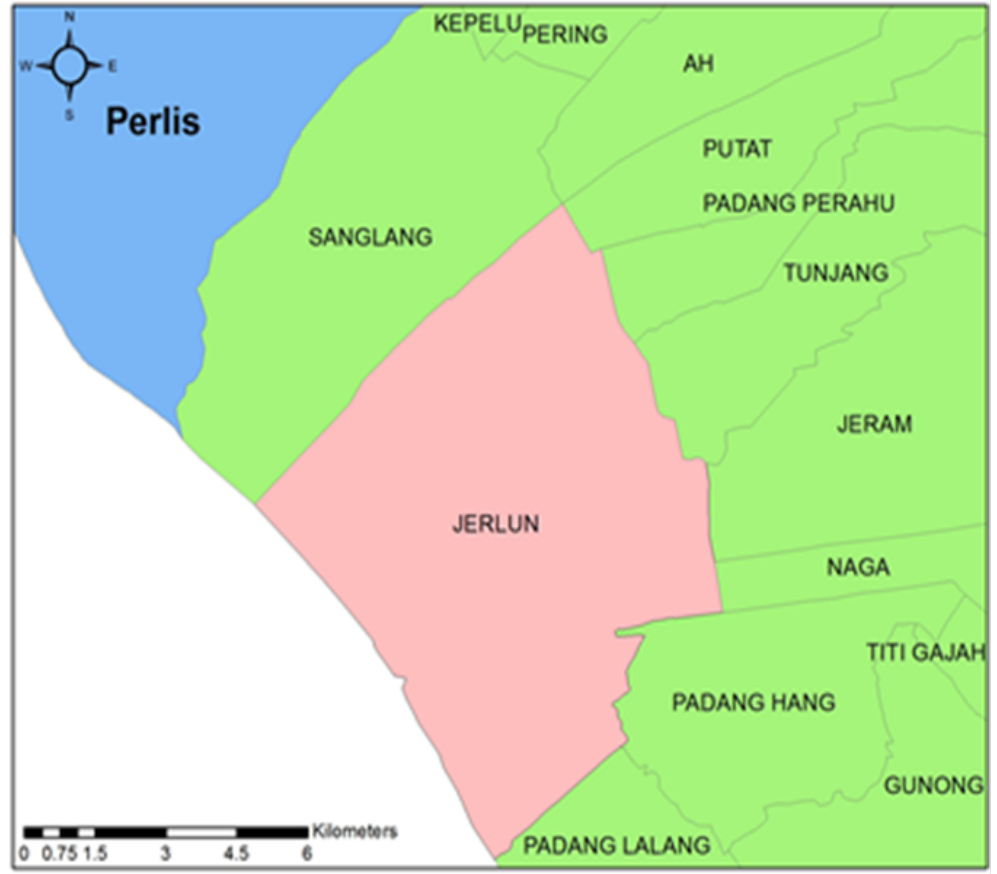

Figure 01. The Study Area 


\section{Findings}

A total of 124 poor households were selected for this study. A total of 108 respondents was surveyed as male and the remaining 16 respondents were female. Respondents' age, background found that $46 \%$ of respondents were between $38-50$ years old. Studies found that the age group was $61 \%$ at least $9 \%$ and the age group was 51-60 years. The study found that the poor people in the question are were actively involved in working and doing kinds of jobs to earn money. The monthly income of the poor in the study area have the average income of RM 801 - RM 1000 which is $51 \%$. Whereas $43 \%$ of the poor have an income of RM 501 - RM 800. Only 3\% of the population have income of RM 200 - RM 500 and 2\% of the poor have income above RM 1000. Table 02 shows a summary of the demographic profile of the respondents in the study area.

Table 02. Summary Profile Demography Respondents

\begin{tabular}{|l|c|c|}
\hline \multicolumn{1}{|c|}{ Demography Profile } & Frequency (people) & Percent \\
\hline Gender & 108 & 87 \\
\hline Male & 16 & 13 \\
\hline Female & \multicolumn{2}{l|}{} \\
\hline Age & 57 & 46 \\
\hline $38-50$ & 56 & 45 \\
\hline $51-60$ & \multicolumn{3}{l|}{} \\
\hline$>60$ & 11 & 9 \\
\hline Monthly Income & 4 & 3 \\
\hline RM 200- RM 500 & 54 & 43 \\
\hline RM 501- RM 800 & 63 & 51 \\
\hline RM 801- RM 1000 & 3 & 2 \\
\hline RM 1001- RM 1300 & & \\
\hline
\end{tabular}

(Source: Fieldwork, 2017)

\subsection{Significant Factors influence land utilization among Poor rural Household}

Based on the multiple regression analysis, the results show that the R correlation coefficient of the dependent variable with the independent variable is 0.559 which shows a good relationship as the value is greater than 0.50 . Accordingly, the $\mathrm{R}^{2}$ value of 0.582 indicates that as much as $58.2 \%$ of the variation in land utilization can be explained in this analysis. While the remaining $42.8 \%$ of the land resource use is influenced by other factors not discussed in this study. Besides, the Adjusted $\mathrm{R}^{2}$ value explains how well the model can be generalized to the population, so ideally the closer the Adjusted $\mathrm{R}^{2}$ value to $\mathrm{R}^{2}$ is. The adjusted value of $\mathrm{R}^{2}$ from the research findings is 0.579 or $57.9 \%$. The difference between $\mathrm{R}^{2}$ and Adjusted $\mathrm{R}^{2}$ values is 0.003 or $0.3 \%$. The standard error of the Estimate (SEE) is 0.363 , where the smaller the SEE value is, the better the model will be in predicting the dependent variables.

Besides that, researchers can also identify the important and powerful independent variables influencing the land utilization in their settlements in Table 03. The strength level of a variable will be expressed by the standardized value of $\beta$. Therefore, it can be said that the most influential variables affecting land utilization are factors of social interaction (the type of social interaction) with a value of $\beta=$ 0.443 followed by a climate change (yield) factor of using $\beta=0.424$ and a type of transportation factor 
having a value of $\beta=-0.294$. This is because this type of social interaction can help households perform various agricultural activities in obtaining agricultural produce. Generally, the interactions that occur are informal social interactions that are co-sponsored by family members, while formal interactions are those involving governmental organizations such as subsidizing the population engaged in agricultural activities. As Siwar \& Chamuri (2006) have argued, social interaction plays an important role in utilizing and managing natural resources among the poor community. Similarly, Ledger (2009), Omar (2016), Umunnakwe (2014) and Xu et al. (2015) have found that social interaction is a prerequisite for assistance or information on more productive and effective management of land resources.

Climate change factors, in turn, are an important second factor influencing land utilization. Climate change is a natural or indirect phenomenon that causes the human activity to change or adapt to these conditions (Phuang, 2011) in particular activities. As in the study of Siwar et al. (2009) have found that most farmers adapt to climate change only on the basis of common actions. This, in turn, results from the impact of agricultural activities such as rice farming, vegetable crops and fruits. Also, statements from the results of the informal interviews of respondents also indicate that climate change also affects land use among the poor.

The physical factor of the type of transport represents the third and most important relationship in influencing the poor to use their land resources. This is because, transport is the heart of man to move from one place to another (Amin \& Manap, 2015). National Economic Consultative Council Report (2001) has proven that transportation is an important element of poor families' lives. Here, the importance of transport to the use of land resources is the transportation of agricultural produce and the movement of the source of the land. According to Shafie and Mahmud (2015) with the availability of transportation that can increase the degree of arrivals to a destination and save on cost and travel time. Accordingly, the regression equation can be generated as in Equation 01:

$$
\mathrm{Y}=8.440+0.531 \mathrm{X} 1+(-0.395 \times 10)+0.483 \times 18
$$

Table 03. Efficiency Test for Factors influence land utilization

\begin{tabular}{|c|c|c|c|c|c|c|c|}
\hline \multirow{2}{*}{ No. } & \multirow[b]{2}{*}{ Model } & \multicolumn{2}{|c|}{$\begin{array}{l}\text { Unstandardized } \\
\text { Coefficients }\end{array}$} & \multirow{2}{*}{$\begin{array}{l}\begin{array}{l}\text { Standardized } \\
\text { Coefficients }\end{array} \\
\text { Beta } \\
\end{array}$} & \multirow{2}{*}{$\mathbf{t}$} & \multirow{2}{*}{ Sig. } & \multirow{2}{*}{ Ranking } \\
\hline & & B & $\begin{array}{l}\text { Std. } \\
\text { Error }\end{array}$ & & & & \\
\hline & (Constants) & 8.440 & 1.577 & - & 5.353 & 0.000 & - \\
\hline $\mathrm{X}_{1}$ & $\begin{array}{l}\text { Type Social } \\
\text { Interaction }\end{array}$ & 0.531 & 0.246 & 0.443 & 2.159 & 0.033 & 1 \\
\hline $\mathrm{X}_{10}$ & $\begin{array}{l}\text { Type of } \\
\text { Transportation }\end{array}$ & -0.395 & 0.170 & -0.294 & -2.331 & 0.022 & 3 \\
\hline $\mathrm{X}_{18}$ & $\begin{array}{l}\text { Climate Change } \\
\text { (yield) }\end{array}$ & 0.483 & 0.168 & 0.424 & 2.875 & 0.005 & 2 \\
\hline
\end{tabular}

\subsection{The relationships between land utilization and yield}

Based on the Table 04, the results show that the correlation coefficient $\mathrm{R}$ for the dependent variable with the independent variable is 0.649 which shows good relationship as the value is greater than 0.50 . Accordingly, the $\mathrm{R}^{2}$ value of 0.602 indicates that up to $60.2 \%$ of the variation in natural resource use factors influenced the land resource benefits that can be described in this analysis. While the remaining $39.9 \%$ of the land source income derived from households is influenced by other factors not discussed in this study. 
Besides, the Adjusted $\mathrm{R}^{2}$ value explains how well the model can be generalized to the population, so ideally the closer the Adjusted $\mathrm{R}^{2}$ value to $\mathrm{R}^{2}$. Adjusted $\mathrm{R}^{2}$ value of the research findings was 0.591 or $59.1 \%$. The difference between the value of $\mathrm{R}^{2}$ and adjusted $\mathrm{R}^{2}$ is 0.011 or $1.1 \%$. The standard error of the Estimate (SEE) is 0.797 , where the smaller the SEE value is, the better the model will be in predicting the dependent variables.

Table 04. Model Summary Multiple Regression

\begin{tabular}{|c|c|c|c|}
\hline \multicolumn{4}{|c|}{ Model Summary } \\
\hline $\mathrm{R}$ & $\mathrm{R}$ Square $\left(\mathrm{R}^{2}\right)$ & Adjusted $\mathrm{R}^{2}$ & $\begin{array}{c}\text { Standard Error of the } \\
\text { Estimate (SEE) }\end{array}$ \\
\hline 0.649 & 0.602 & 0.591 & 0.797 \\
\hline
\end{tabular}

According to Table 05 , it was shown that there were only five variables with significant $p$ values $<0.05$, namely variable types of social interaction and social interaction form, type of infrastructure facilities, size of transportation and climate change. Besides, the t-test conducted by the researcher was to measure the significance of each independent variable coefficient on the dependent variable. In addition, researchers are also able to identify important and powerful independent variables in influencing the use of natural resources in their settlements. The strength level of a variable will be expressed by the standardized value of $\beta$.

Therefore, it can be said that the strongest variables related to land resource use are the types and forms of social interaction that have values $\beta=-0.676$ and 0.468 . Variable types of social interactions show inverse relationships with the benefits derived from land use. This is because, the type of interaction refers to one person's interaction with another person. So, this shows that, in the use of land resources, the poor do not need to interact with many people as they will provide little if they are evenly distributed. Therefore, the results indicate a negative relationship. Varying forms of social interaction, however, show a direct relationship to the benefits that poor people derive from land use. This is because the forms of social interaction that are often involved are formal interactions with government and private entities and informal interactions that help to improve outcomes, especially in the agricultural sector such as subsidy assistance, labor assistance and so on. Thus, the results indicate a direct relationship between social interaction factors and the benefits of land resources. Next, it is followed by the variable type of infrastructure facility $\beta=$ 0.316 that is the third most important factor affecting the benefit of land resource use. The relationship between these types of infrastructure facilities is positive in that they are directly proportional to the benefits that the poor benefit from the use of land resources. The type of infrastructure that is important to the poor in the use of land resources is a way of facilitating their movement of land resources to profit.

Transport also plays an important role in influencing land-use outcomes. This study shows that the size of the transport has a positive relationship that the larger the transport is then the more people can bring the result is $\beta=0.310$. Based on field observations, most of the crops that require large-scale transportation are mainly rice and local fruits such as mangoes, rambutans, and bananas. While the climate change enabler recorded a value of $\beta=0.260$, it also showed a positive relationship. In other words, climate change has a direct bearing on the use of land resources especially in crops. Climate change, such as prolonged heat, will cause plants or plants to die from the lack of water in the soil and therefore the yield for the poor will be 
affected. So climate change is also affecting the use of land resources among the poor. A summary of important and powerful independent variables influencing land resource use can be found in Table 5. Accordingly, the regression equation can be generated as in Equation 02;

$$
\mathrm{Y}=1.765+(-1.126 \mathrm{x} 1)+0.769 \mathrm{x} 3+0.541 \mathrm{x} 8+0.689 \mathrm{x}_{11}+0.450 \mathrm{x} 17 \quad \ldots \text { Equation } 02
$$

Table 05. Efficiency Test for Factors influence Land Utilization with Yield of Land resources

\begin{tabular}{|c|c|c|c|c|c|c|c|}
\hline \multirow{2}{*}{ No. } & \multirow{2}{*}{ Model } & \multicolumn{2}{|c|}{$\begin{array}{c}\text { Unstandardized } \\
\text { Coefficients }\end{array}$} & $\begin{array}{c}\text { Standardized } \\
\text { Coefficients }\end{array}$ & \multirow{2}{*}{$\mathbf{t}$} & \multirow{2}{*}{ Sig. } & \multirow{2}{*}{ Ranking } \\
\cline { 2 - 7 } & $\mathbf{B}$ & $\begin{array}{c}\text { Std. } \\
\text { Error }\end{array}$ & Beta & & \\
\hline & (Constant) & 1.765 & 2.354 & - & .750 & 0.455 & - \\
\hline $\mathrm{X}_{1}$ & $\begin{array}{c}\text { Type of social } \\
\text { interaction }\end{array}$ & -1.126 & 0.360 & -0.676 & -3.125 & 0.002 & $\mathbf{1}$ \\
\hline $\mathrm{X}_{3}$ & Social Interaction form & 0.769 & 0.348 & 0.468 & 2.208 & 0.029 & $\mathbf{2}$ \\
\hline $\mathrm{X}_{8}$ & $\begin{array}{c}\text { Type of infrastructure } \\
\text { facilities }\end{array}$ & 0.541 & 0.264 & 0.316 & 2.052 & 0.043 & $\mathbf{3}$ \\
\hline $\mathrm{X}_{11}$ & Size of transportation & 0.689 & 0.352 & 0.310 & 1.954 & 0.043 & $\mathbf{4}$ \\
\hline $\mathrm{X}_{17}$ & Climate change (yield) & 0.450 & 0.232 & 0.260 & 1.942 & 0.049 & $\mathbf{5}$ \\
\hline
\end{tabular}

\section{Conclusion}

The key finding of this study is, the poor people in the rural area utilize land resources in the surrounding area in their settlement are also influenced by social factors (social interaction), physical factors (transportation) and risk factors (climate change) in obtaining the benefits generated by the process of the ecosystem. As a conclusion, land utilizes is generating multiple activities to increase household income portfolio and to maintain their livelihood. Other than that, poor people utilize the land resources is to ensure household from insufficiency of food, thereby improving their food security status, while equally lessening their vulnerability to hunger. With that, the poor people should utilize the multiple natural resources had available in their settlements without having to focus on just one source of food supply. These findings offer information for decision-makers to improve strategies of poverty alleviation programs. On a bigger scale, the strategies used by the poor also provide important information for sustainable livelihood for the local communities, by going back to nature and encourage self-sufficient living environment. The limitation of the study is that, focuses only on poor household in a rural area and should utilize the land resources surrounding area in their settlement. We would like to suggest further research to be conducted on the factors influence utilization, natural resources among the poor and non-poor people in the rural area and urban area.

\section{Acknowledgments}

We would like to acknowledge the support from the RU Team "Spatial Inequalities, Framing Phenomena, Formulating Policies". (001/PHUMANITI/856002). 


\section{References}

Abdullah, N., F., \& Mustafa, B., F. (2011). Tumbuhan di Kawasan Sekitar Rumah Kampung To' Uban Pasir Mas, Kelantan. [Plants in the Neighborhood of Kampung to 'Liw Pasir Mas, Kelantan]. Universiti Malaya, Kuala Lumpur.

Amin, A. S., \& Manap, J. (2015). Geografi, Kemiskinan dan Wanita Kurang Upaya di Malaysia [Geography, poverty and Malaysian disabled women]. Malaysia Journal of Society and Space 11, $7(7), 82-91$.

Bakar, A., B. (2007). Kaedah Analisis Data Penyelidikan Ilmiah. [Methods for Scientific Research Analyzing Data]. Utusan Publications \& Distributors Sdn. Bhd. Kuala Lumpur.

Braat, L. C., \& de Groot, R. (2012). The ecosystem services agenda: bridging the worlds of natural science and economics, conservation and development, and public and private policy. Ecosystem Services, 1(1), 4-15. https://doi.org/10.1016/j.ecoser.2012.07.011

Constantine, D. (2016). Executive Recommended 2016 Comprehensive Plan. Chapter 3: Rural Areas and Natural Resource Lands. Douglas St: King County, Office of Performance, Strategy and Budget.

Dunnamah, A. Y., Williams, J. J., Hamangamdo, W. W., \& Kwale, J. M. (2016). The Role of Traditional Religion and Socio-Cultural Practices in the Natural Resources Conservation and Management of the Lunguda Land, Adamawa/Gombe State Nigeria. International Journal of Education and Research, 4(5), 37-52. www.ijern.com

Fonta, W. M., Email, T., \& Ayuk, E. (2011). The Distributional Impacts of Forest Income on Household Welfare in Rural Nigeria. Journal of Economics and Sustainable Development, 2(1), 1-13. http://www.iiste.org/Journals/index.php/JEDS/article/view/130

Hetzler, E. (2012). The Interconnection of Environment and Poverty: Prospects for Sustainable Development. University of Colorado Boulder.

Hussain, M. Y., Manaf, A. A., Ramli, Z., \& Saad, S. (2017). Kesejahteraan sosial masyarakat nelayan: Kajian kes di Kampung Sri Bahagia, Mersing, Johor [The social well-being of a Malaysian fishing community: The case of Kampong Bahagia, Mersing, Johor]. Geografia-Malaysian Journal of Society and Space, 7(5), 80-90.

Kamwi, J. M., Chirwa, P. W. C., Graz, F. P., Manda, S. O. M., Mosimane, A. W., \& Kätsch, C. (2018). Livelihood activities and skills in rural areas of the Zambezi region, Namibia: Implications for policy and poverty reduction. African Journal of Food, Agriculture, Nutrition and Development, 18(1), 13074-13094.

Kubang Pasu District Council. (2016). http://mpkubangpasu.gov.my/

Ledger, J. (2009). Consequences of the introduction of the Modified Taungya System in Ghana's High Forest Zone for the livelihoods of forest-fringe communities. Forestry Research Institute of Ghana, Ghana.

Millenium Ecosystem Assessment. (2005). Ecosystem and Human Well-being Synthesis. Ecosystem (Vol.5). Island Press.

Ministry of Women, Family and Community Development. (2014). Data E-Kasih. https://ekasih.icu.gov.my

National Economic Consultative Council Report. (2001). Retrieved from pustaka.upsi.edu.my.

Ngang, D. F. (2015). The Contribution of Community-Based Natural Resources Management to Livelihoods, Conservation and Governance in Cameroon. A Comparative Assessment of Three Community Forests. (Doctoral dissertation). Pan African Institute for Development. West Africa.

Nyumbu, M. E. (2013). Poverty and Environment: A Case Study of Stone Crushing as a Sustainable Livelihood in Lasuka. University of South Africa. Africa.

Omar, N. (2016). Ekologi Keluarga Dan Kesejahteraan Hidup Kanak-Kanak Miskin Di Malaysia. [Family Ecology and the Wellbeing of Poor Children in Malaysia]. (Doctoral dissertation). University Malaya. Kuala Lumpur.

Organisation for Economic Co-Operation and Development. (2008). Annual report on sustainable development work in the OECD. Retrieved from https://www.oecd.org/greengrowth 
Phuang, L. T. H. (2011). Climate change and farmers' adaptation: A case study of mixed -farming systems in the coastal area in Trieu Van commune, Trieu Phong district, Quang Tri province, Vietnam. Swedish University of Agricultural Sciences.

Selim, R., Sohani, F., \& Ifthekharul, H. (2009). Access to land and other natural resources by the rural poor: the case of Bangladesh. Economic Policy. https://mpra.ub.uni-muenchen.de/38621

Shafie, M., H., S \& Mahmud, M. (2015). Spatial distribution analysis of PM10 and O3 in the Klang Valley using Geographic Information System (GIS). Malaysian Journal of Society and Space, 3(3), 61-73.

Siwar, C., \& Chamuri, N. (2006). Poverty and environment: A review of issues and evidences of Malaysia. In Readings in World Developments: Growth \& Development in the Asia Pacific (pp. 87-102). Nova Science Publishers, Inc.

Siwar, C., Alam, M., Murad, M., \& Al-Amin, A. Q. (2009). A review of the linkages between climate change, agricultural sustainability and poverty in Malaysia. International Review of Business Research Papers, 5(6), 309-321.

Thongyou, M. (2014). Rubber cash crop and changes in livelihoods strategies in a village in Northeastern Thailand. Asian Social Science, 10(13), 239-251.

Umunnakwe, V. C. (2014). Factors influencing the involvement in non-agricultural income generating activities of rural youth: A case study in Jabalpur district of Madhya Pradesh, India. Journal of the University of Ruhuna, 2(1-2), 24-32.

Xu, D., Zhang, J., Rasul, G., Liu, S., Xie, F., Cao, M., \& Liu, E. (2015). Household Livelihood Strategies and Dependence on Agriculture in the Mountainous Settlements in the Three Gorges Reservoir Area, China. Sustainability, 7(5), 4850-4869. http://www.mdpi.com/2071-1050/7/5/4850/ 